\title{
Liquid Biopsy for Cancer: Circulating Tumor Cells, Circulating Free DNA or Exosomes?
}

\author{
Wei Zhanga,b Wenjie Xia ${ }^{a, c}$ Zhengye Lv ${ }^{c}$ Yin Xin ${ }^{c}$ Chao Nia,c Liu Yang ${ }^{a}$ \\ aKey Laboratory of Tumor Molecular Diagnosis and Individual Medicine of Zhejiang Province, \\ bDepartment of Endocrinology, ' Department of General surgery, Zhejiang Provincial People's Hospital, \\ People's Hospital of Hangzhou Medical College, Hangzhou, China
}

\section{Key Words}

Liquid biopsy $•$ Circulating tumor cells $•$ Circulating free DNA $・$ Exosomes

\begin{abstract}
Precision medicine and personalized medicine are based on the development of biomarkers, and liquid biopsy has been reported to be able to detect biomarkers that carry information on tumor development and progression. Compared with traditional 'solid biopsy', which cannot always be performed to determine tumor dynamics, liquid biopsy has notable advantages in that it is a noninvasive modality that can provide diagnostic and prognostic information prior to treatment, during treatment and during progression. In this review, we describe the source, characteristics, technology for detection and current situation of circulating tumor cells, circulating free DNA and exosomes used for diagnosis, recurrence monitoring, prognosis assessment and medication planning.
\end{abstract}

\section{Introduction}

Cancer is a leading cause of death globally, and precision medicine has been one of the most exciting areas for cancer therapy in recent years [1]. Traditional biomarkers and imaging techniques play important roles in tumor diagnosis; however, the specificity of traditional serum biomarkers is unsatisfactory for therapeutic guidance. Additionally, imaging techniques cannot be used for 'real-time' detection due to radiation exposure and economic concerns [2-5]. In contrast, liquid biopsy has increasingly been considered for early tumor diagnosis, therapeutic guidance and recurrence monitoring due to the abundant information that it can provide about tumors [6]. Additionally, liquid biopsy provides a noninvasive alternative to traditional 'solid biopsy', which cannot be consistently performed in certain situations or in 'real time'. Despite these numerous advantages, several limitations remain, such as a lack of consensus on detection methods, difficulty in the analysis of 


\section{Cellular Physiology Cell Physiol Biochem 2017;41:755-768

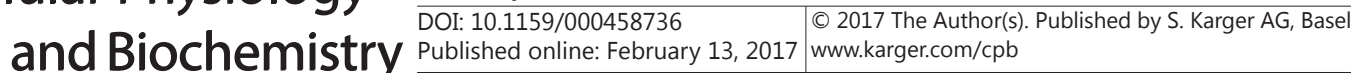 \\ Zhang et al.: Comparison of CTCs, cfDNA and Exosomes}

overwhelming sequencing information and insufficient proof grounded in evidence-based medicine.

In this review, we describe and compare the source, characteristics, technology of detection and current situation of circulating tumor cells (CTCs), cell-free DNA (cfDNA) and exosomes used for the diagnosis of and recurrence monitoring, prognosis assessment and medication planning for solid tumors.

\section{The source and characteristics of CTCs, cfDNA and exosomes}

Thomas Ashworth discovered CTCs in the 1860s while using a microscope to examine peripheral blood; the theory that tumor cells could penetrate the vessel wall and enter the circulatory system was then proposed [7]. Several studies later found that solid tumor cells could break into the bloodstream via both passive and active approaches [8-11] (Fig. 1). Notably, most CTCs were found to be 'accidental CTCs' that were passively pushed by external forces, such as tumor growth, mechanical forces during surgical operation or friction [12]. However, very few tumor cells undergo the epithelial-mesenchymal transition (EMT) process, allowing these cells to exhibit more plasticity and metastatic potential [1315]. Although thousands of tumor cells can leak into the vasculature through any of the above pathways, most CTCs are eliminated via the bloodstream. The natural obstacles to their survival include anoikis, shearing forces due to blood flow and immune cell attack [16-18]. In recent years, platelets have also been revealed to be the most important patron of CTCs: platelets specifically promote tumor cells' EMT in the primary lesion and then aggregate above the tumor cells to form a shield in the bloodstream. Platelets are additionally used by CTCs to facilitate adhesion to distant organs and the occurrence of the EMT to allow formation of a metastatic lesion [19-21].

In addition to complete tumor cells, these cells' genetic content is also found in the blood circulation (Fig. 1). Similar to CTCs, cfDNA has been hypothesized to be passively or actively released as well [22]. The passive mechanism suggests that dead tumor cells release DNA or RNA into the circulation, whereas certain in vitro and in vivo experiments found that tumor cell lines could spontaneously release DNA fragments into the circulation [23, 24]. Garcia-Olmo et al. found that colon cancer cell-derived cfDNA could induce oncogenic transformation of murine embryonic fibroblasts and distant metastasis [25], which demonstrated that cfDNA is more deeply involved in cancer progression than only serving as a biomarker. In healthy individuals, apoptotic cells and cfDNA are nearly completely cleared, and the level of cfDNA is very low, whereas in malignant tumors, chronic inflammation and excessive cell death lead to the accumulation of cell debris, which results in insufficient clearance [26, 27]. This mechanism provides a rational explanation for the positive relationship between the tumor burden and the cfDNA amount observed in cancer patients. CTCs can also release DNA into the vasculature [28]. However, previous reports found that few CTCs are in the circulation (less than 10 cells in $7.5 \mathrm{ml}$ peripheral blood) [29]; therefore, CTCs do not represent the primary resource of cfDNA.

Exosomes are small (30-140 $\mathrm{nm}$ ) membrane-bound particles that originate from large multivesicular bodies (MVBs) and are released into the extracellular environment by fusion of MVBs with the plasma membrane, and they have been revealed as a promising biomarker in multiple diseases (Fig. 1). Exosomes can also be released in large quantities in various biological fluids, such as plasma, urine, saliva, ascites and bronchoalveolar lavage fluid. They were first considered to only be involved in the removal of unnecessary molecules, but numerous interesting studies have since illuminated exosomes' complex function in tumor progression and metastasis. A number of cell types have been described as releasing exosomes, such as epithelial cells, hematopoietic cells, neuronal cells, fibroblasts, adipocytes and tumor cells [30]. Because of their cellular origin, exosomes present specific biomarkers, such as members of the tetraspanin family (CD63, CD9 and CD81), heat-shock proteins (such as HSP70) and the Rab protein family [31]. Although the size of exosomes is similar between 
normal and malignant cells, the exosome protein concentration is higher in advanced-stage cancer, and the protein, mRNA and miRNA profiles of exosomes also differ from those of exosomes' cells of origin [32,33]. These specific exosomes can alter the microenvironment through their protein and RNA cargo. For example, melanoma-derived exosomes can induce vascular leakiness at pre-metastatic sites, and intra-exosome Met oncoprotein educates bone marrow progenitors toward a c-Kit+Tie2+Met+ pro-vasculogenic phenotype [32]. Additionally, bone marrow stroma-derived exosomes are transported to breast cancer cells and contribute to these cells' quiescence via CXCL-12 targeting of miRNAs [34]. Moreover, CD81+ exosomes derived from cancer-associated fibroblasts activate Wnt-PCP signaling in breast cancer cells to promote invasiveness [35]. Thus, in light of their crucial role in cell-cell communication and tumor-specific content, exosomes represent a promising biomarker for early tumor detection and monitoring and medication planning.

\section{Technology for detecting CTCs, cfDNA and exosomes}

The key challenge in CTC detection is CTC rarity, which makes it difficult to estimate the number of single tumor cells among millions of surrounding normal peripheral blood cells (with even fewer tumor cells in early-stage cancer patients) [36, 37]. Hence, a number of technologies have been developed to achieve maximum CTC enrichment. Based on their detection principle, CTC enrichment and detection methods can be classified into cell surface marker-dependent and marker-independent approaches. Most cell surface markerdependent approaches involve positive selection, which relies on epithelial cell markers, usually EpCAM and cytokeratin [38]. The CELLSEARCH system is the only U.S. FDA-approved technique to detect CTCs, and abundant clinical trials have demonstrated the prognostic value of determining CTC numbers with this technology. Additionally, CTC-chips have been applied in various platforms to improve the capture ability of CTCs. The CTC-chip is composed of a microfluidic platform containing antibody (against EpCAM or MUC1)-coated microposts that interact with and capture CTCs, which increases the sensitivity and yield and simplifies the step of pre-labeling samples [39-41]. However, several types of tumor cells lack epithelial markers (such as triple-negative breast cancer and melanoma) that can be enriched using approaches that combine negative selection (CD45-) and size-based methods (density centrifugation or filtration), such as the ISET system or the ScreenCell approach [42-44]. In addition to the above-mentioned novel strategies, it is worth noting that CTC metastasis requires the EMT process ; hence, transformed tumor cells can lose epithelial markers, so epithelial-type tumor cells may not be the culprit. Yu et al. [45] reported that rare primary tumor cells simultaneously expressed mesenchymal and epithelial markers; however, mesenchymal cells were highly enriched in CTCs, and serial CTC monitoring in 11 patients suggested an association between mesenchymal-type CTCs, but not epithelial-type CTCs, and disease progression. Hence, we propose that CTCs should be comprehensively detected and allocated into epithelial (epithelial+/mesenchymal), complete EMT (epithelial/ mesenchymal+), and intermediate EMT (epithelial+/mesenchymal+) phenotypes.

Obtaining and analyzing cfDNA is substantially more challenging than doing so for CTCs due to the small fraction of cfDNA within the high amount of DNA originating from normal tissue. Usually, whole blood is collected in EDTA-coated tubes, followed by centrifugation to remove cells, and cfDNA is then extracted using commercial kits. With the exception of the sample preparation, the most challenging step is determining cancer-specific aberrations in the cfDNA [46]. At present, advanced techniques have been developed to detect DNA aberrations primarily based on digital PCR and next-generation sequencing (NGS). Digital PCR technology has commonly been applied to detect targeted DNA aberrations, and approaches involving digital PCR primarily include microfluidic platforms [47, 48]; the use of beads, emulsions, amplification and magnetics (BEAMing) [49]; and droplet-based systems [50]. Although PCR-based technology has very high sensitivity, which can be used to monitor tumor-associated genetic aberrations at frequencies as low as $0.01 \%$ [51], this technology can 


\section{Cellular Physiology and Biochemistry Published online: rebruary 13, 2017 www.karger.com/cpb

Fig. 1. Schematic of the origin of cfDNA, CTCs and exosomes in the blood. cfDNA can be released from healthy, inflamed or tumor tissue undergoing apoptosis or necrosis. Tumor cells can also actively intrude the circulatory system or can be pushed into the bloodstream by external forces, such as tumor growth or mechanical forces during surgical operation. These tumor cells can be shielded by platelets. Moreover, circulating exosomes can be generated by many cell types, including tumor cells, normal cells, and blood cells (even platelets). Abbreviations: cfDNA, cell-free DNA; CTCs, circulating tumor cells.

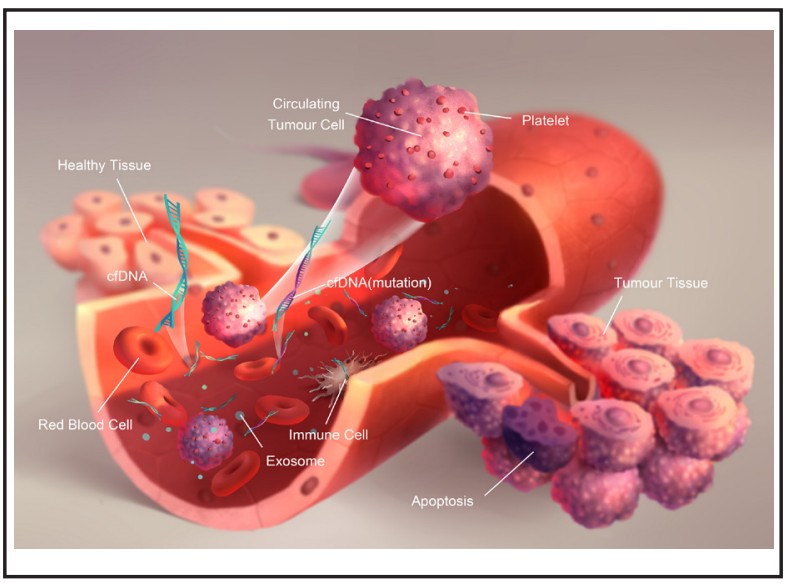

only detect limited numbers of foci. Considering the spatial and longitudinal heterogeneity of tumor cells, DNA mutations may vary under the pressure of treatment or among different tumor subclones; therefore, digital PCR technology may miss substantial information during the monitoring process. To overcome this issue, NGS technologies are now applied to obtain a more comprehensive view of entire genomic regions. Approaches involving deep sequencing include Safe-Seq [52], TAm-Seq [48], CAPP-Seq [53] and AmpliSeq [54]. With these technologies, NGS provides opportunities to characterize personalized cancer gene maps and develop personalized medicine. Rothe et al. first conducted deep-coverage NGS in patients with advanced breast cancer to detect mutations in the hotspot regions of 50 genes and found discordant mutations between the DNA originating from the primary tumor and the plasma in $24 \%$ of the patients [54]. However, the high cost (2500 dollars in China) and especially the complications in data management impede this technology's clinical application. Additionally, deep sequencing yields an incredible amount of information, making it difficult to distinguish between tumor-specific aberrations and background noise, which can be due to sequencing errors or library preparation. Nevertheless, continued improvements in the sensitivity of genomic technology and bioinformatics will allow NGS techniques to play a central role in cfDNA analysis.

The isolation of exosomes ideally not only yields large quantities of purified exosomes but also facilitates analysis, such as analysis of the proteins, DNA and miRNA in exosomes. Conventional methods of exosome isolation are based on a series of centrifugation steps to exclude cells and cell debris and require more than 10 hours of ultracentrifugation; however, these remain the most economical protocols, especially when large numbers of exosomes are required $[55,56]$. Several commercial kits and patented approaches have been developed to improve and simplify the exosome isolation process; Urbanelli et al. [57] comprehensively reviewed exosome isolation methods to date. In brief, exosomes can be isolated via ultrafiltration plus size exclusion chromatography, precipitation with polymers and immunoaffinity purification using magnetic beads. Each method has advantages and drawbacks. For example, UC-SEC uses a solid matrix to isolate highly purified exosomes; however, it is difficult to remove contaminating proteins [58]. Polymeric precipitation was invented by System Biosciences (SBI) in 2009, with the trade name ExoQuick. This technology functions by capturing exosomes of a certain size $(60-150 \mathrm{~nm})$ in $30 \mathrm{~min}$ and yields more exosomes than ultracentrifugation; however, it cannot avoid mixing of non-exosomal contents with a similar size, such as apoptotic debris or other types of microvesicles [59]. Additionally, exosomes can be isolated using an immunoaffinity method to selectively isolate classic CD9+, CD63+ or CD81+ exosomes, with the captured exosomes retaining bioactivity for downstream analysis. The immunoaffinity method can only be applied to a small-volume sample and only isolates exosomes with specific markers, which may limit the experimental findings. Exosomes are rich in RNA transcripts; thus, following isolation and validation via electron microscopy, the RNA contents of exosomes can be analyzed using qPCR and NGS. 


\section{Cellular Physiology Cell Physiol Biochem 2017;41:755-768

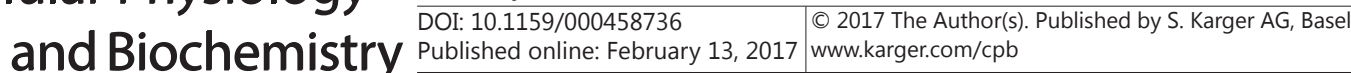 \\ Zhang et al.: Comparison of CTCs, cfDNA and Exosomes}

In addition to RNA, several types of protein have been reported to play important roles in cell-cell communication. Using proteomic techniques, such as mass spectrometry, Melo et al. [60] identified that a cell surface proteoglycan, glypican-1 (GPC1), could be applied as an exosome marker in breast cancer and pancreatic cancer patients. Furthermore, the CD24+ exosome has been reported to be a potential marker for diagnosing ovarian cancer [61]. In conclusion, integrated systems for exosome isolation and detection have been established to facilitate exosome research.

\section{Diagnosis and prognosis assessment}

Liquid biopsy was reported to possess higher sensitivity and to be more convenient for cancer diagnosis compared with traditional imaging and biopsy strategies. CTC detection in particular has been applied in monitoring epithelium-originating tumors in clinical trials $[62,63]$. However, debate continues regarding cfDNA and CTCs in cancer diagnosis and monitoring. Several studies found that cfDNA appears earlier than CTCs in the serum of cancer patients $[64,65]$; however, interestingly, other studies reported that cfDNA was inferior to CTCs as a marker in lung cancer, and especially non-small-cell lung cancer [29, $41,66]$. Notably, because exosomes can be detected in multiple body fluids, such as serum, plasma, urine, ascites and saliva, they have also been revealed to be a very promising biomarker for cancer diagnosis and progression monitoring. We will now discuss the above in further detail.

\section{Diagnosis}

Many cancer treatment breakthroughs have been achieved in recent decades; however, early diagnosis remains one of the most difficult aspects. The early diagnosis of cancer currently relies on image examination, such as via ultrasound, CT or MRI, or on serum biomarkers. Although imaging has been and remains the gold standard in solid tumor screening and monitoring, emerging approaches have been reported to possess higher sensitivity. Murray et al. [67] performed a prospective study to test the diagnostic value of CTCs in patients with mammography results indicating a BI-RADS category of 3 or more; CTCs were defined as negative for CD45 and positive for mammaglobin. CTCs were found in $87 \%$ of invasive cancers but in only $50 \%$ of in situ cancers and in no intraductal cancers. Among women misdiagnosed with benign disease, the mean time to the development of imaging-detected invasive carcinoma was 9 years [68]; therefore, the authors proposed that a combination of CTC detection with imaging could be a better choice. The early diagnostic value of CTCs in lung cancer has also been validated. Ilie et al. [69] conducted a prospective study to examine the presence of CTCs in chronic obstructive pulmonary disease patients without detectable lung cancer. CTCs were detected using an ISET filtration-enrichment technique. Five patients (5/168) with CTC positivity were determined to have lung nodules via CT scan 1-4 years after CTC detection; subsequent surgical resection and pathological examination diagnosed early-stage lung cancer. The controls, without CTCs, were not found to have lung cancer in the same period. This study revealed a substantially higher sensitivity for CTCs in early cancer diagnosis. Furthermore, the early diagnosis of cancer via CTC detection challenges the notion of 'early-stage cancer' or 'carcinoma in situ', which has been considered to be a local disease. In an animal model, CTCs were found very early, in the 'carcinoma in situ' stage [70], and tumor cells were found to spread for many years prior to diagnosis (with a high probability) [71, 72]. The above evidence indicates that CTCs may be a useful tool for early cancer diagnosis.

In addition to CTC detection, detecting circulating free DNA is a promising strategy in early cancer diagnosis. Abundant studies have shown a positive relationship between the cfDNA level and the tumor stage. Bettegowda et al. [73] evaluated cfDNA in localized malignant disease and found that $72,57,48$, and $50 \%$ of patients with colorectal cancer, gastroesophageal cancer, pancreatic cancer, and breast cancer, respectively, could be 
identified via cfDNA analysis. Additionally, $47 \%$ of patients with stage I cancers of any type had detectable cfDNA, whereas the fractions of patients with detectable cfDNA were 55, 69 , and $82 \%$ for patients with stage II, III, and IV cancers, respectively. However, another large prospective nested case-control study failed to draw this conclusion based on an analysis of 334 subjects with solid tumors and 166 subjects with leukemia. The geometric mean of the cfDNA concentrations was $28 \mathrm{ng} / \mathrm{mL}$ in the controls and varied between 29 and $36 \mathrm{ng} / \mathrm{mL}$ in the various cancer groups, but this difference was not significant [74]. Due to this controversy, several studies have attempted to predict early cancer with known DNA mutations using digital PCR. Colorectal cancer is a malignant disease with several well-known mutated genes, such as KRAS, APC and TP53. To test the predictive value of the quantification and KRAS status of cfDNA in plasma from high-risk subjects (age > 50 years and positive fecal blood test), a study was performed in 170 patients with colorectal lesions (12 with adenocarcinoma, 22 with high-grade intraepithelial neoplasia (HGIN), and 73 with premalignant lesions (adenomas and hyperplasia)) and 63 healthy controls. The results revealed predictive value for the cfDNA level in adenocarcinoma (AUC 0.709; 95\% CI, 0.508-0.909); however, the KRAS mutation rate in the plasma was drastically lower than that in adjacent adenocarcinoma or HGIN tissue (3\% vs 45\%) [75]. This finding contrasted with a finding of more KRAS mutations in the serum than in the primary tumor [76]. In conclusion, the use of cfDNA quantification to predict malignancies is promising but requires further investigation.

Alterations in circulating miRNAs have also been revealed to be informative in each stage of various malignant diseases, such as lung cancer, colorectal cancer and pancreatic cancer [77-79]. As miRNAs would be degraded in the circulation, circulating miRNAs are packed into various membrane-bound vesicles, such as exosomes, microvesicles, and apoptotic bodies, or exist in a vesicle-free form associated with lipoprotein complexes. Among these options, exosomes are believed to be an important source. In diethylnitrosamine-induced hepatocellular carcinoma (HCC), Liu et al. [80] found that the levels of miRNA-10b, miRNA-21, miRNA-122 and miRNA-200a in exosomes were changed in cirrhosis (this is in contrast with alpha-fetoprotein, whose levels rise until early-stage HCC). Additionally, these four miRNAs were more remarkably changed during the HCC stage. Another four selected miRNAs (miR1246, miR-4644, miR-3976 and miR-4306) were found to be significantly upregulated in the serum exosomes of pancreatic cancer patients but rarely in control groups, and the concomitant evaluation of pancreatic cancer-initiating cells and miRNA serum exosome marker panels even reached a diagnostic specificity of 0.93 (95\% CI, 0.81-0.98) [81]. The above studies offer considerable evidence that exosome miRNAs can be applied as a valuable tool in cancer diagnosis; however, the heterogeneous results (even among similar cancer types) hamper the interpretation and reliability of miRNAs as cancer biomarkers in clinical diagnosis [82, 83]. Furthermore, several biomarkers in serum exosomes have been suggested to be good candidate diagnostic and theranostic markers in patients with colorectal cancer, pancreatic cancer and breast cancer, such as HSP60 and GPC1, which are expected to be validated in more studies with larger samples.

\section{Prognosis and treatment indications}

In a pooled analysis, we recently found that the presence of more CTCs in metastatic breast cancer (MBC) was significantly associated with a poorer outcome and that HER2 positivity, but not hormonal receptor expression, in primary tumors and triple-negative breast cancer was associated with more CTCs. Furthermore, a CTC count $\geq 5$ indicated a worse treatment response in MBC patients [84]. The prognostic value of CTC enumeration has been demonstrated in abundant types of tumors, such as those in prostate cancer, lung cancer, pancreatic cancer and colorectal cancer, via large clinical trials and pooled analyses [85-89]. In early breast cancer (stage I-II), we found that CTCs were rarely detectable in $7.5 \mathrm{ml}$ of blood using CELLSEARCH or CanPatrol technology (data not shown). Several other researchers reported that CTC detection predicted relapse in high-risk operable breast cancer [90-92]. However, the negative result of a prospective study performed by the 


\section{Cellular Physiology Cell Physiol Biochem 2017;41:755-768 \\ \begin{tabular}{ll|l} 
and Biochemistry & $\begin{array}{l}\text { DOI: 10.1159/000458736 } \\
\text { Published online: February 13, } 2017\end{array}$ & $\begin{array}{l}\text { 2017 The Author(s). Published by S. Karger AG, Basel } \\
\text { ww.com/cpb }\end{array}$ \\
\cline { 2 - 3 }
\end{tabular} \\ Zhang et al.: Comparison of CTCs, cfDNA and Exosomes}

Southwest Oncology Group (S0500) postponed the utilization of CTC detection for treatment decision-making [93]. The S0500 trial specifically assessed the benefit of an early change in the chemotherapy regimen of patients with persistent increases in CTCs and failed to find that it improved overall survival (OS). Additionally, more and more evidence has shown that certain subtypes of CTCs, such as HER2+ or mesenchymal-type CTCs, and circulating tumor mammospheres are responsible for tumor metastasis, but this is not the case for the majority of CTCs, so it is still too early to conclude whether CTCs can provide information for treatment guidance.

In contrast with CTCs, the prognostic information offered by cfDNA is based on measuring single tumor-specific aberrations. KRAS mutations have been found to be related to poor prognosis in several types of malignant disease. In a multivariate analysis, a KRAS mutation in the plasma of patients with non-small-cell lung cancer, pancreatic cancer or colorectal cancer was shown to predict poor OS and a high risk of recurrence [94-96]. APC and TP53 aberrations were found to have high sensitivity and specificity in predicting disease relapse in colorectal cancer, breast cancer, lung cancer and oral squamous-cell carcinoma [97-99]. The amplification of MYCN (a MYC-related oncogene) in neuroblastoma has been identified as a strong risk factor for a poor outcome, whereas immunotherapy has been found to effectively increase disease-free and overall survival in $M Y C N$-amplified neuroblastoma [100, 101]. Positive results of the phase III BELLE- 2 trial were presented at the 2015 San Antonio Breast Cancer Symposium [102]. In this study, 1,147 patients with advanced hormonal receptorpositive breast cancer that had become resistant to aromatase inhibitor therapy received the estrogen-receptor antagonist fulvestrant alone or in combination with the PI3K inhibitor buparlisib. The PIK3CA mutation status was evaluated in 387 tissue specimens and 587 blood samples. Among patients who had PIK3CA mutations detected in their cfDNA, progressionfree survival was significantly longer (7.0 months) if they received the combination therapy compared with fulvestrant alone (3.2 months), whereas negative results were found in patients with PIK3CA mutations detected in the tissue. Although sequencing for several known targeted genes (such as TP53, PIK3CA and KRAS) may provide useful information, whole-genome sequencing can identify more somatic mutations and thus may be more valuable in prognosis prediction. Dawson et al. [47] carried out a prospective single-center study to compare the sensitivity of measuring circulating free DNA, CA 15-3, and CTCs to monitor the tumor burden in patients with MBC. Their results revealed that cfDNA is the most sensitive approach for predicting treatment response and outcome. Additionally, whole-genome sequencing identified more than $50 \%$ of patients with structural variants, in whom no mutations in PIK3CA or TP53 were found, and in contrast with CA 15-3 and CTCs, quantifying tumor-associated genetic mutations was the most sensitive approach to patient stratification according to their survival probability. Although the above evidence indicated that cfDNA is a promising prognostic marker that may also be used for treatment guidance, this finding remains to be validated in larger clinical trials.

In contrast with the use of CTCs and cfDNA, the use of the tumor exosome as a prognostic biomarker and for treatment guidance primarily depends on its protein and miRNA expression profiles. It is reported $\beta$-Elemene could reverse the chemoresistance by downregulate multidrug resistance microRNA in exosomes derived from chemoresistant breast cancer cell lines [103]. Low expression of miR-718 in exosomes in HCC has been reported as a risk factor for tumor recurrence after liver transplantation [104]. Moreover, the downregulation of exosomal miR-92a in HCC is associated with cancer progression and a high risk of recurrence [105], and the overexpression of exosomal miR-21-3p indicates cisplatin resistance in ovarian cancer [106]. Additionally, higher expression of migration inhibitory factor (MIF) in exosomes in pancreatic ductal adenocarcinoma (PDAC) primes the liver for metastasis and may represent a prognostic marker for the development of PDAC liver metastasis [107]. Rab27a regulates the generation and release of exosomes into the extracellular space; however, the targeted inhibition of Rab27a was found to lead to a dramatic disappearance of endosome-associated exosomes, whereas CD9- and Mfge8positive vesicles were unaffected [108], which indicates that further evaluation is needed to

\section{KARGER}




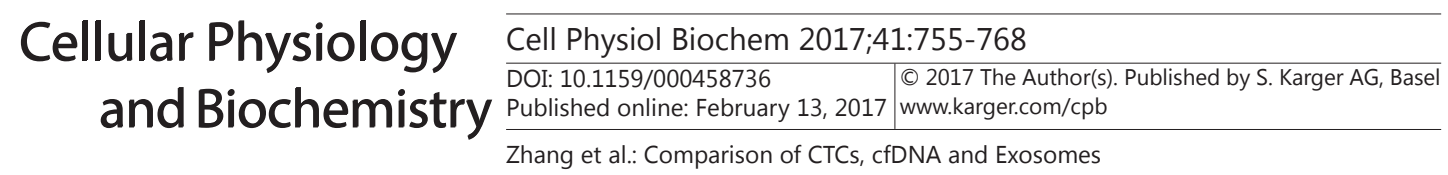

Table 1. Comparison of three liquid biopsy methods (CTCs, cfDNA and exosomes). Abbreviations: CTCs, circulating tumor cells; cfDNA, circulating free DNA; BEAMing, beads, emulsion, amplification, magnetics; $\mathrm{NGS}$, next generation sequencing

\begin{tabular}{|c|c|c|c|c|}
\hline & Source & $\begin{array}{l}\text { Enrich or analytic } \\
\text { technique }\end{array}$ & Strength & Limitation \\
\hline \multirow[t]{3}{*}{ CTCs } & Peripheral blood & $\begin{array}{l}\text { Label dependent (e.g. } \\
\text { CELLSEARCH) }\end{array}$ & Noninvasive & $\begin{array}{l}\text { Impact of heterogeneity on various CTC enrichment } \\
\text { methods }\end{array}$ \\
\hline & & & $\begin{array}{l}\text { High specificity of tumor-derived } \\
\text { Ex vivo functional studies available }\end{array}$ & $\begin{array}{l}\text { Controversy of guiding therapeutic decision making } \\
\text { Instability of monitoring early stage cancer }\end{array}$ \\
\hline & & $\begin{array}{l}\text { Label independent (e.g. } \\
\text { ISET system, ScreenCell) }\end{array}$ & $\begin{array}{l}\text { Approved by FDA in clinical practice (CELLSEARCH) } \\
\text { Non-coding RNA, DNA and protein all could be } \\
\text { evaluated }\end{array}$ & \\
\hline cfDNA & Serum or plasma & $\begin{array}{l}\text { PCR(e.g. BEAMing, } \\
\text { digital PCR, Amplicon } \\
\text { sequencing) }\end{array}$ & $\begin{array}{l}\text { Noninvasive } \\
\text { High sensitivity }\end{array}$ & $\begin{array}{l}\text { Difficult to determine cancer-specific aberration } \\
\text { Superabundant data from NGS cause it's difficult to } \\
\text { distinguish background noise from true tumour } \\
\text { associated aberrations }\end{array}$ \\
\hline \multirow[t]{3}{*}{ Exosomes } & $\begin{array}{l}\text { Plasma and other } \\
\text { body fluids (ex. } \\
\text { urine, saliva, }\end{array}$ & $\begin{array}{l}\text { Ultracentrifugation } \\
\text { Immunoaffinity methods }\end{array}$ & $\begin{array}{l}\text { Noninvasive (available in multiple body fluids) } \\
\text { Ex vivo functional studies available }\end{array}$ & $\begin{array}{l}\text { tumor derived exosomes lack specific marker } \\
\text { Impact of heterogeneity on various exosomes } \\
\text { enrichment methods }\end{array}$ \\
\hline & ascites) & Chromatography & $\begin{array}{l}\text { Non-coding RNA, DNA and protein all could be } \\
\text { evalutaed }\end{array}$ & $\begin{array}{l}\text { Lack of large clinical trials to validate its reliability in } \\
\text { clinical practice }\end{array}$ \\
\hline & & ExoQuick polymer & & \\
\hline
\end{tabular}

characterize and differentiate the different subpopulations of exosomes and to determine their biological function in tumor progression. Additionally, although many exosomal proteins and miRNAs have been proposed as prognostic markers and therapeutic targets, most have only been investigated in small cohorts or cell lines. Thus, more studies are needed to further characterize exosomal proteins and miRNAs and to assess their value in analyzing cancer progression and determining the treatment direction.

\section{Conclusion}

Liquid biopsy plays an important role in the precision medicine field in that it represents a noninvasive cancer therapy strategy that can be molded to an individual's characteristics and biological features. In contrast with conventional imaging examination and tumor markers, liquid biopsy is more sensitive and accurate and provides substantially more information regarding prognosis and treatment direction.

However, many hurdles need to be overcome before proceeding with use in the clinical setting. The advantage and limitation of three liquid biopsy methods are summarized in this review (Table 1). The primary problem is a lack of standard and convenient techniques. CELLSEARCH is the only technique approved by the FDA to detect CTCs; however, dozens of techniques have shown advantages regarding CTC capture capacity and subgrouping of CTCs based on various markers. Regarding cfDNA detection, it lacks standardized steps for extracting DNA to be used for the quantification of tumor-associated genetic mutations (via digital PCR, NGS or BEAMing). There is a similar problem for exosomes, with a lack of a rapid and high-yield approach for extracting exosomes for downstream analysis. Another important issue is how to select tumor markers. For instance, it remains impossible to distinguish between CTCs with high and low metastatic capacity as well as between exosomes derived from tumor and normal tissues. Additionally, how to analyze cfDNA and whether commercial multiple-mutation panels (such as those for NGS) should be used to screen large panels of genes for individuals remain substantial challenges. Finally, although many studies have been performed to prove the clinical utility of liquid biopsy, most were retrospective, so more rigorous studies are required to validate the substantial potential of liquid biopsy. 


\section{Cellular Physiology Cell Physiol Biochem 2017;41:755-768

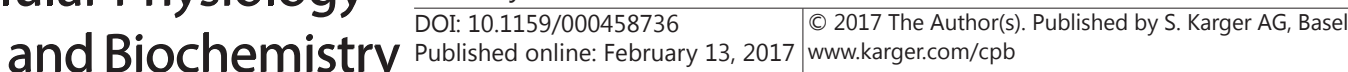 \\ Zhang et al.: Comparison of CTCS, cfDNA and Exosomes}

\section{Funding support}

This work was supported by Science and Technology Department of Zhejiang Province (grant number LY15H160053, LQ15H070004), the Natural Science Foundation of China (grant number 31200652), and the public welfare program of Zhejiang Province Science and Technology Hall (grant number 2015C33097).

\section{Disclosure Statement}

The authors declare that they have no competing interests.

\section{References}

1 Biankin AV, Piantadosi S, Hollingsworth SJ: Patient-centric trials for therapeutic development in precision oncology. Nature 2015;526:361-370.

-2 Tubiana M: Radiation risks in perspective: Radiation-induced cancer among cancer risks. Radiat Environ Biophys 2000;39:3-16.

3 Elkind MM: Enhanced risks of cancer from protracted exposures to x- or gamma-rays: A radiobiological model of radiation-induced breast cancer. Br J Cancer 1996;73:133-138.

4 Mattsson S, Nilsson M: On the estimation of radiation-induced cancer risks from very low doses of radiation and how to communicate these risks. Radiat Prot Dosimetry 2015;165:17-21.

-5 Ruckert F, Pilarsky C, Grutzmann R: Serum tumor markers in pancreatic cancer-recent discoveries. Cancers (Basel) 2010;2:1107-1124.

-6 Sestini S, Boeri M, Marchiano A, Pelosi G, Galeone C, Verri C, Suatoni P, Sverzellati N, La Vecchia C, Sozzi G, Pastorino U: Circulating microrna signature as liquid-biopsy to monitor lung cancer in low-dose computed tomography screening. Oncotarget 2015;6:32868-32877.

7 Joosse SA, Pantel K: Biologic challenges in the detection of circulating tumor cells. Cancer Res 2013;73:811.

8 Thiery JP: Epithelial-mesenchymal transitions in tumour progression. Nat Rev Cancer 2002;2:442-454.

-9 Thiery JP, Lim CT: Tumor dissemination: An emt affair. Cancer Cell 2013;23:272-273.

10 Tsuji T, Ibaragi S, Hu GF: Epithelial-mesenchymal transition and cell cooperativity in metastasis. Cancer Res 2009;69:7135-7139.

11 Tsuji T, Ibaragi S, Shima K, Hu MG, Katsurano M, Sasaki A, Hu GF: Epithelial-mesenchymal transition induced by growth suppressor p12cdk2-ap1 promotes tumor cell local invasion but suppresses distant colony growth. Cancer Res 2008;68:10377-10386.

12 McDonald DM, Baluk P: Significance of blood vessel leakiness in cancer. Cancer Res 2002;62:5381-5385.

13 Hong Y, Zhang Q: Phenotype of circulating tumor cell: Face-off between epithelial and mesenchymal masks. Tumour Biol 2016;37:5663-5674.

14 Krebs MG, Metcalf RL, Carter L, Brady G, Blackhall FH, Dive C: Molecular analysis of circulating tumour cells-biology and biomarkers. Nat Rev Clin Oncol 2014;11:129-144.

-15 Cristofanilli M, Budd GT, Ellis MJ, Stopeck A, Matera J, Miller MC, Reuben JM, Doyle GV, Allard WJ, Terstappen LW, Hayes DF: Circulating tumor cells, disease progression, and survival in metastatic breast cancer. N Engl J Med 2004;351:781-791.

16 Mitchell MJ, King MR: Computational and experimental models of cancer cell response to fluid shear stress. Front Oncol 2013;3:44.

17 Douma S, Van Laar T, Zevenhoven J, Meuwissen R, Van Garderen E, Peeper DS: Suppression of anoikis and induction of metastasis by the neurotrophic receptor trkb. Nature 2004;430:1034-1039.

18 Steinert G, Scholch S, Niemietz T, Iwata N, Garcia SA, Behrens B, Voigt A, Kloor M, Benner A, Bork U, Rahbari NN, Buchler MW, Stoecklein NH, Weitz J, Koch M: Immune escape and survival mechanisms in circulating tumor cells of colorectal cancer. Cancer Res 2014;74:1694-1704. 


\section{Cellular Physiology Cell Physiol Biochem 2017;41:755-768 and Biochemistry Published \begin{tabular}{l|l|l} 
DO 2017 The Author(s). Published by S. Karger AG, Basel \\
www.karger.com/cpb
\end{tabular}}

Zhang et al.: Comparison of CTCs, cfDNA and Exosomes

19 Cooke NM, Spillane CD, Sheils O, O'Leary J, Kenny D: Aspirin and p2y12 inhibition attenuate plateletinduced ovarian cancer cell invasion. BMC Cancer 2015;15:627.

20 Kopp HG, Placke T, Salih HR: Platelet-derived transforming growth factor-beta down-regulates nkg2d thereby inhibiting natural killer cell antitumor reactivity. Cancer Res 2009;69:7775-7783.

-21 Schumacher D, Strilic B, Sivaraj KK, Wettschureck N, Offermanns S: Platelet-derived nucleotides promote tumor-cell transendothelial migration and metastasis via p2y2 receptor. Cancer Cell 2013;24:130-137.

22 Crowley E, Di Nicolantonio F, Loupakis F, Bardelli A: Liquid biopsy: Monitoring cancer-genetics in the blood. Nat Rev Clin Oncol 2013;10:472-484.

-23 Stroun M, Lyautey J, Lederrey C, Olson-Sand A, Anker P: About the possible origin and mechanism of circulating DNA apoptosis and active DNA release. Clin Chim Acta 2001;313:139-142.

-24 Anker P, Stroun M, Maurice PA: Spontaneous release of DNA by human blood lymphocytes as shown in an in vitro system. Cancer Res 1975;35:2375-2382.

-25 Garcia-Olmo DC, Dominguez C, Garcia-Arranz M, Anker P, Stroun M, Garcia-Verdugo JM, Garcia-Olmo D: Cell-free nucleic acids circulating in the plasma of colorectal cancer patients induce the oncogenic transformation of susceptible cultured cells. Cancer Res 2010;70:560-567.

26 Pisetsky DS, Fairhurst AM: The origin of extracellular DNA during the clearance of dead and dying cells. Autoimmunity 2007;40:281-284.

27 Viorritto IC, Nikolov NP, Siegel RM: Autoimmunity versus tolerance: Can dying cells tip the balance? Clin Immunol 2007;122:125-134.

28 Akca H, Demiray A, Yaren A, Bir F, Koseler A, Iwakawa R, Bagci G, Yokota J: Utility of serum DNA and pyrosequencing for the detection of egfr mutations in non-small cell lung cancer. Cancer Genet 2013;206:73-80.

29 Punnoose EA, Atwal S, Liu W, Raja R, Fine BM, Hughes BG, Hicks RJ, Hampton GM, Amler LC, Pirzkall A, Lackner MR: Evaluation of circulating tumor cells and circulating tumor DNA in non-small cell lung cancer: Association with clinical endpoints in a phase ii clinical trial of pertuzumab and erlotinib. Clin Cancer Res 2012;18:2391-2401.

-30 van der Pol E, Boing AN, Harrison P, Sturk A, Nieuwland R: Classification, functions, and clinical relevance of extracellular vesicles. Pharmacol Rev 2012;64:676-705.

-31 Taylor DD, Gercel-Taylor C: Exosomes/microvesicles: Mediators of cancer-associated immunosuppressive microenvironments. Semin Immunopathol 2011;33:441-454.

-32 Peinado H, Aleckovic M, Lavotshkin S, Matei I, Costa-Silva B, Moreno-Bueno G, Hergueta-Redondo M, Williams C, Garcia-Santos G, Ghajar C, Nitadori-Hoshino A, Hoffman C, Badal K, Garcia BA, Callahan MK, Yuan J, Martins VR, Skog J, Kaplan RN, Brady MS, Wolchok JD, Chapman PB, Kang Y, Bromberg J, Lyden D: Melanoma exosomes educate bone marrow progenitor cells toward a pro-metastatic phenotype through met. Nat Med 2012;18:883-891.

33 Grange C, Tapparo M, Collino F, Vitillo L, Damasco C, Deregibus MC, Tetta C, Bussolati B, Camussi G: Microvesicles released from human renal cancer stem cells stimulate angiogenesis and formation of lung premetastatic niche. Cancer Res 2011;71:5346-5356.

-34 Lim PK, Bliss SA, Patel SA, Taborga M, Dave MA, Gregory LA, Greco SJ, Bryan M, Patel PS, Rameshwar P: Gap junction-mediated import of microrna from bone marrow stromal cells can elicit cell cycle quiescence in breast cancer cells. Cancer Res 2011;71:1550-1560.

-35 Luga V, Zhang L, Viloria-Petit AM, Ogunjimi AA, Inanlou MR, Chiu E, Buchanan M, Hosein AN, Basik M, Wrana JL: Exosomes mediate stromal mobilization of autocrine wnt-pcp signaling in breast cancer cell migration. Cell 2012;151:1542-1556.

-36 Alix-Panabieres C, Pantel K: Challenges in circulating tumour cell research. Nat Rev Cancer 2014;14:623631.

37 Rack B, Schindlbeck C, Juckstock J, Andergassen U, Hepp P, Zwingers T, Friedl TW, Lorenz R, Tesch H, Fasching PA, Fehm T, Schneeweiss A, Lichtenegger W, Beckmann MW, Friese K, Pantel K, Janni W, Group SS: Circulating tumor cells predict survival in early average-to-high risk breast cancer patients. J Natl Cancer Inst 2014;106

- 38 Parkinson DR, Dracopoli N, Petty BG, Compton C, Cristofanilli M, Deisseroth A, Hayes DF, Kapke G, Kumar P, Lee J, Liu MC, McCormack R, Mikulski S, Nagahara L, Pantel K, Pearson-White S, Punnoose EA, Roadcap LT, Schade AE, Scher HI, Sigman CC, Kelloff GJ: Considerations in the development of circulating tumor cell technology for clinical use. J Transl Med 2012;10:138. 


\section{Cellular Physiology Cell Physiol Biochem 2017;41:755-768 and Biochemistry DOI: 10.1159/000458736 2017 (O) 2017 The Author(s). Published by S. Karger AG, Basel \\ Zhang et al.: Comparison of CTCs, cfDNA and Exosomes}

39 Thege FI, Lannin TB, Saha TN, Tsai S, Kochman ML, Hollingsworth MA, Rhim AD, Kirby BJ: Microfluidic immunocapture of circulating pancreatic cells using parallel epcam and muc1 capture: Characterization, optimization and downstream analysis. Lab Chip 2014;14:1775-1784.

40 Nagrath S, Sequist LV, Maheswaran S, Bell DW, Irimia D, Ulkus L, Smith MR, Kwak EL, Digumarthy S, Muzikansky A, Ryan P, Balis UJ, Tompkins RG, Haber DA, Toner M: Isolation of rare circulating tumour cells in cancer patients by microchip technology. Nature 2007;450:1235-1239.

-41 Maheswaran S, Sequist LV, Nagrath S, Ulkus L, Brannigan B, Collura CV, Inserra E, Diederichs S, Iafrate AJ, Bell DW, Digumarthy S, Muzikansky A, Irimia D, Settleman J, Tompkins RG, Lynch TJ, Toner M, Haber DA: Detection of mutations in egfr in circulating lung-cancer cells. N Engl J Med 2008;359:366-377.

42 Wu S, Liu Z, Liu S, Lin L, Yang W, Xu J: Enrichment and enumeration of circulating tumor cells by efficient depletion of leukocyte fractions. Clin Chem Lab Med 2014;52:243-251.

43 Ozkumur E, Shah AM, Ciciliano JC, Emmink BL, Miyamoto DT, Brachtel E, Yu M, Chen PI, Morgan B, Trautwein J, Kimura A, Sengupta S, Stott SL, Karabacak NM, Barber TA, Walsh JR, Smith K, Spuhler PS, Sullivan JP, Lee RJ, Ting DT, Luo X, Shaw AT, Bardia A, Sequist LV, Louis DN, Maheswaran S, Kapur R, Haber DA, Toner M: Inertial focusing for tumor antigen-dependent and -independent sorting of rare circulating tumor cells. Sci Transl Med 2013;5:179ra147.

44 Kallergi G, Politaki E, Alkahtani S, Stournaras C, Georgoulias V: Evaluation of isolation methods for circulating tumor cells (ctcs). Cell Physiol Biochem 2016;40:411-419.

45 Yu M, Bardia A, Wittner BS, Stott SL, Smas ME, Ting DT, Isakoff SJ, Ciciliano JC, Wells MN, Shah AM, Concannon KF, Donaldson MC, Sequist LV, Brachtel E, Sgroi D, Baselga J, Ramaswamy S, Toner M, Haber DA, Maheswaran S: Circulating breast tumor cells exhibit dynamic changes in epithelial and mesenchymal composition. Science 2013;339:580-584.

46 Ma M, Zhu H, Zhang C, Sun X, Gao X, Chen G: "Liquid biopsy"-ctdna detection with great potential and challenges. Ann Transl Med 2015;3:235.

-47 Dawson SJ, Tsui DW, Murtaza M, Biggs H, Rueda OM, Chin SF, Dunning MJ, Gale D, Forshew T, Mahler-Araujo B, Rajan S, Humphray S, Becq J, Halsall D, Wallis M, Bentley D, Caldas C, Rosenfeld N: Analysis of circulating tumor DNA to monitor metastatic breast cancer. N Engl J Med 2013;368:1199-1209.

-48 Forshew T, Murtaza M, Parkinson C, Gale D, Tsui DW, Kaper F, Dawson SJ, Piskorz AM, Jimenez-Linan M, Bentley D, Hadfield J, May AP, Caldas C, Brenton JD, Rosenfeld N: Noninvasive identification and monitoring of cancer mutations by targeted deep sequencing of plasma DNA. Sci Transl Med 2012;4:136ra168.

-49 Dressman D, Yan H, Traverso G, Kinzler KW, Vogelstein B: Transforming single DNA molecules into fluorescent magnetic particles for detection and enumeration of genetic variations. Proc Natl Acad Sci U S A 2003;100:8817-8822.

-50 Hindson BJ, Ness KD, Masquelier DA, Belgrader P, Heredia NJ, Makarewicz AJ, Bright IJ, Lucero MY, Hiddessen AL, Legler TC, Kitano TK, Hodel MR, Petersen JF, Wyatt PW, Steenblock ER, Shah PH, Bousse LJ, Troup CB, Mellen JC, Wittmann DK, Erndt NG, Cauley TH, Koehler RT, So AP, Dube S, Rose KA, Montesclaros L, Wang S, Stumbo DP, Hodges SP, Romine S, Milanovich FP, White HE, Regan JF, Karlin-Neumann GA, Hindson CM, Saxonov S, Colston BW: High-throughput droplet digital pcr system for absolute quantitation of DNA copy number. Anal Chem 2011;83:8604-8610.

-51 Chan KC, Jiang P, Zheng YW, Liao GJ, Sun H, Wong J, Siu SS, Chan WC, Chan SL, Chan AT, Lai PB, Chiu RW, Lo YM: Cancer genome scanning in plasma: Detection of tumor-associated copy number aberrations, singlenucleotide variants, and tumoral heterogeneity by massively parallel sequencing. Clin Chem 2013;59:211224.

52 Kinde I, Wu J, Papadopoulos N, Kinzler KW, Vogelstein B: Detection and quantification of rare mutations with massively parallel sequencing. Proc Natl Acad Sci U S A 2011;108:9530-9535.

53 Newman AM, Bratman SV, To J, Wynne JF, Eclov NC, Modlin LA, Liu CL, Neal JW, Wakelee HA, Merritt RE, Shrager JB, Loo BW, Jr., Alizadeh AA, Diehn M: An ultrasensitive method for quantitating circulating tumor DNA with broad patient coverage. Nat Med 2014;20:548-554.

-54 Rothe F, Laes JF, Lambrechts D, Smeets D, Vincent D, Maetens M, Fumagalli D, Michiels S, Drisis S, Moerman C, Detiffe JP, Larsimont D, Awada A, Piccart M, Sotiriou C, Ignatiadis M: Plasma circulating tumor DNA as an alternative to metastatic biopsies for mutational analysis in breast cancer. Ann Oncol 2014;25:1959-1965.

-55 Turchinovich A, Weiz L, Langheinz A, Burwinkel B: Characterization of extracellular circulating microrna. Nucleic Acids Res 2011;39:7223-7233. 


\section{Cellular Physiology Cell Physiol Biochem 2017;41:755-768

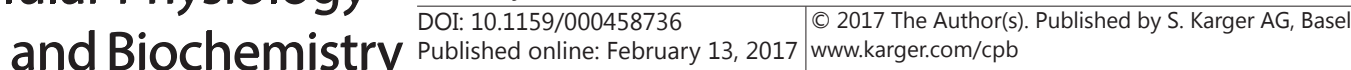 \\ Zhang et al: Comparison of CTCS, cfDNA and Exosomes}

56 Wagner J, Riwanto M, Besler C, Knau A, Fichtlscherer S, Roxe T, Zeiher AM, Landmesser U, Dimmeler S: Characterization of levels and cellular transfer of circulating lipoprotein-bound micrornas. Arterioscler Thromb Vasc Biol 2013;33:1392-1400.

-57 Urbanelli L, Buratta S, Sagini K, Ferrara G, Lanni M, Emiliani C: Exosome-based strategies for diagnosis and therapy. Recent Pat CNS Drug Discov 2015;10:10-27.

58 Sabapatha A, Gercel-Taylor C, Taylor DD: Specific isolation of placenta-derived exosomes from the circulation of pregnant women and their immunoregulatory consequences. Am J Reprod Immunol 2006;56:345-355.

-59 Taylor DD, Zacharias W, Gercel-Taylor C: Exosome isolation for proteomic analyses and rna profiling. Methods Mol Biol 2011;728:235-246.

-60 Melo SA, Luecke LB, Kahlert C, Fernandez AF, Gammon ST, Kaye J, LeBleu VS, Mittendorf EA, Weitz J, Rahbari N, Reissfelder C, Pilarsky C, Fraga MF, Piwnica-Worms D, Kalluri R: Glypican-1 identifies cancer exosomes and detects early pancreatic cancer. Nature 2015;523:177-182.

61 Zhao Z, Yang Y, Zeng Y, He M: A microfluidic exosearch chip for multiplexed exosome detection towards blood-based ovarian cancer diagnosis. Lab Chip 2016;16:489-496.

62 Krebs MG, Hou JM, Ward TH, Blackhall FH, Dive C: Circulating tumour cells: Their utility in cancer management and predicting outcomes. Ther Adv Med Oncol 2010;2:351-365.

63 Esmaeilsabzali H, Beischlag TV, Cox ME, Parameswaran AM, Park EJ: Detection and isolation of circulating tumor cells: Principles and methods. Biotechnol Adv 2013;31:1063-1084.

64 Tu M, Chia D, Wei F, Wong D: Liquid biopsy for detection of actionable oncogenic mutations in human cancers and electric field induced release and measurement liquid biopsy (elb). Analyst 2016;141:393402.

65 Thierry AR, Mouliere F, El Messaoudi S, Mollevi C, Lopez-Crapez E, Rolet F, Gillet B, Gongora C, Dechelotte P, Robert B, Del Rio M, Lamy PJ, Bibeau F, Nouaille M, Loriot V, Jarrousse AS, Molina F, Mathonnet M, Pezet D, Ychou M: Clinical validation of the detection of kras and braf mutations from circulating tumor DNA. Nat Med 2014;20:430-435.

66 Kuang Y, Rogers A, Yeap BY, Wang L, Makrigiorgos M, Vetrand K, Thiede S, Distel RJ, Janne PA: Noninvasive detection of egfr t790m in gefitinib or erlotinib resistant non-small cell lung cancer. Clin Cancer Res 2009;15:2630-2636.

67 Murray NP, Miranda R, Ruiz A, Droguett E: Diagnostic yield of primary circulating tumor cells in women suspected of breast cancer: The best (breast early screening test) study. Asian Pac J Cancer Prev 2015;16:1929-1934.

68 Collins LC, Tamimi RM, Baer HJ, Connolly JL, Colditz GA, Schnitt SJ: Outcome of patients with ductal carcinoma in situ untreated after diagnostic biopsy: Results from the nurses' health study. Cancer 2005;103:1778-1784.

69 Ilie M, Hofman V, Long-Mira E, Selva E, Vignaud JM, Padovani B, Mouroux J, Marquette CH, Hofman P: "Sentinel" circulating tumor cells allow early diagnosis of lung cancer in patients with chronic obstructive pulmonary disease. PLoS One 2014;9:e111597.

70 Rhim AD, Mirek ET, Aiello NM, Maitra A, Bailey JM, McAllister F, Reichert M, Beatty GL, Rustgi AK, Vonderheide RH, Leach SD, Stanger BZ: Emt and dissemination precede pancreatic tumor formation. Cell 2012;148:349-361.

71 Gray JW: Evidence emerges for early metastasis and parallel evolution of primary and metastatic tumors. Cancer Cell 2003;4:4-6.

72 Michaelson JS, Cheongsiatmoy JA, Dewey F, Silverstein MJ, Sgroi D, Smith B, Tanabe KK: Spread of human cancer cells occurs with probabilities indicative of a nongenetic mechanism. Br J Cancer 2005;93:12441249.

73 Bettegowda C, Sausen M, Leary RJ, Kinde I, Wang Y, Agrawal N, Bartlett BR, Wang H, Luber B, Alani RM, Antonarakis ES, Azad NS, Bardelli A, Brem H, Cameron JL, Lee CC, Fecher LA, Gallia GL, Gibbs P, Le D, Giuntoli RL, Goggins M, Hogarty MD, Holdhoff M, Hong SM, Jiao Y, Juhl HH, Kim JJ, Siravegna G, Laheru DA, Lauricella C, Lim M, Lipson EJ, Marie SK, Netto GJ, Oliner KS, Olivi A, Olsson L, Riggins GJ, Sartore-Bianchi A, Schmidt K, Shih I M, Oba-Shinjo SM, Siena S, Theodorescu D, Tie J, Harkins TT, Veronese S, Wang TL, Weingart JD, Wolfgang CL, Wood LD, Xing D, Hruban RH, Wu J, Allen PJ, Schmidt CM, Choti MA, Velculescu VE, Kinzler KW, Vogelstein B, Papadopoulos N, Diaz LA, Jr.: Detection of circulating tumor DNA in early- and late-stage human malignancies. Sci Transl Med 2014;6:224ra224. 


\section{Cellular Physiology Cell Physiol Biochem 2017;41:755-768

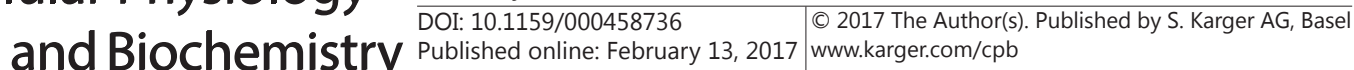 \\ Zhang et al.: Comparison of CTCs, cfDNA and Exosomes}

74 Gormally E, Vineis P, Matullo G, Veglia F, Caboux E, Le Roux E, Peluso M, Garte S, Guarrera S, Munnia A, Airoldi L, Autrup H, Malaveille C, Dunning A, Overvad K, Tjonneland A, Lund E, Clavel-Chapelon F, Boeing H, Trichopoulou A, Palli D, Krogh V, Tumino R, Panico S, Bueno-de-Mesquita HB, Peeters PH, Pera G, Martinez C, Dorronsoro M, Barricarte A, Navarro C, Quiros JR, Hallmans G, Day NE, Key TJ, Saracci R, Kaaks R, Riboli E, Hainaut P: Tp53 and kras2 mutations in plasma DNA of healthy subjects and subsequent cancer occurrence: A prospective study. Cancer Res 2006;66:6871-6876.

-75 Perrone F, Lampis A, Bertan C, Verderio P, Ciniselli CM, Pizzamiglio S, Frattini M, Nucifora M, Molinari F, Gallino G, Gariboldi M, Meroni E, Leo E, Pierotti MA, Pilotti S: Circulating free DNA in a screening program for early colorectal cancer detection. Tumori 2014;100:115-121.

-76 Ramirez JL, Sarries C, de Castro PL, Roig B, Queralt C, Escuin D, de Aguirre I, Sanchez JM, Manzano JL, Margeli M, Sanchez JJ, Astudillo J, Taron M, Rosell R: Methylation patterns and k-ras mutations in tumor and paired serum of resected non-small-cell lung cancer patients. Cancer Lett 2003;193:207-216.

-77 Ganepola GA, Rutledge JR, Suman P, Yiengpruksawan A, Chang DH: Novel blood-based microrna biomarker panel for early diagnosis of pancreatic cancer. World J Gastrointest Oncol 2014;6:22-33.

78 Fesler A, Jiang J, Zhai H, Ju J: Circulating microrna testing for the early diagnosis and follow-up of colorectal cancer patients. Mol Diagn Ther 2014;18:303-308.

79 Shao Y, Geng Y, Gu W, Huang J, Pei H, Jiang J: Prognostic role of tissue and circulating microrna-200c in malignant tumors: A systematic review and meta-analysis. Cell Physiol Biochem 2015;35:1188-1200.

-80 Liu WH, Ren LN, Wang X, Wang T, Zhang N, Gao Y, Luo H, Navarro-Alvarez N, Tang LJ: Combination of exosomes and circulating micrornas may serve as a promising tumor marker complementary to alpha-fetoprotein for early-stage hepatocellular carcinoma diagnosis in rats. J Cancer Res Clin Oncol 2015;141:1767-1778.

81 Madhavan B, Yue S, Galli U, Rana S, Gross W, Muller M, Giese NA, Kalthoff H, Becker T, Buchler MW, Zoller M: Combined evaluation of a panel of protein and mirna serum-exosome biomarkers for pancreatic cancer diagnosis increases sensitivity and specificity. Int J Cancer 2015;136:2616-2627.

-82 Ono S, Lam S, Nagahara M, Hoon DS: Circulating microrna biomarkers as liquid biopsy for cancer patients: Pros and cons of current assays. J Clin Med 2015;4:1890-1907.

-83 Jackson BL, Grabowska A, Ratan HL: Microrna in prostate cancer: Functional importance and potential as circulating biomarkers. BMC Cancer 2014;14:930.

84 Lv Q, Gong L, Zhang T, Ye J, Chai L, Ni C, Mao Y: Prognostic value of circulating tumor cells in metastatic breast cancer: A systemic review and meta-analysis. Clin Transl Oncol 2016;18:322-330.

85 Ignatiadis M, Lee M, Jeffrey SS: Circulating tumor cells and circulating tumor DNA: Challenges and opportunities on the path to clinical utility. Clin Cancer Res 2015;21:4786-4800.

86 Ma XL, Li YY, Zhang J, Huang JW, Jia HY, Liu L, Li P: Prognostic role of circulating tumor cells in patients with pancreatic cancer: A meta-analysis. Asian Pac J Cancer Prev 2014;15:6015-6020.

87 Wang S, Zheng G, Cheng B, Chen F, Wang Z, Chen Y, Wang Y, Xiong B: Circulating tumor cells (ctcs) detected by rt-pcr and its prognostic role in gastric cancer: A meta-analysis of published literature. PLoS One 2014;9:e99259.

88 Ma X, Xiao Z, Li X, Wang F, Zhang J, Zhou R, Wang J, Liu L: Prognostic role of circulating tumor cells and disseminated tumor cells in patients with prostate cancer: A systematic review and meta-analysis. Tumour Biol 2014;35:5551-5560.

89 Groot Koerkamp B, Rahbari NN, Buchler MW, Koch M, Weitz J: Circulating tumor cells and prognosis of patients with resectable colorectal liver metastases or widespread metastatic colorectal cancer: A metaanalysis. Ann Surg Oncol 2013;20:2156-2165.

90 Ignatiadis M, Xenidis N, Perraki M, Apostolaki S, Politaki E, Kafousi M, Stathopoulos EN, Stathopoulou A, Lianidou E, Chlouverakis G, Sotiriou C, Georgoulias V, Mavroudis D: Different prognostic value of cytokeratin-19 mrna positive circulating tumor cells according to estrogen receptor and her2 status in early-stage breast cancer. J Clin Oncol 2007;25:5194-5202.

91 Pierga JY, Bidard FC, Mathiot C, Brain E, Delaloge S, Giachetti S, de Cremoux P, Salmon R, VincentSalomon A, Marty M: Circulating tumor cell detection predicts early metastatic relapse after neoadjuvant chemotherapy in large operable and locally advanced breast cancer in a phase ii randomized trial. Clin Cancer Res 2008;14:7004-7010. 


\section{Cellular Physiology Cell Physiol Biochem 2017;41:755-768

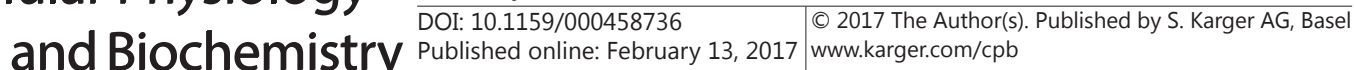 \\ Zhang et al.: Comparison of CTCs, cfDNA and Exosomes}

\$2 Lucci A, Hall CS, Lodhi AK, Bhattacharyya A, Anderson AE, Xiao L, Bedrosian I, Kuerer HM, Krishnamurthy S: Circulating tumour cells in non-metastatic breast cancer: A prospective study. Lancet Oncol 2012;13:688-695.

93 Smerage JB, Barlow WE, Hortobagyi GN, Winer EP, Leyland-Jones B, Srkalovic G, Tejwani S, Schott AF, O'Rourke MA, Lew DL, Doyle GV, Gralow JR, Livingston RB, Hayes DF: Circulating tumor cells and response to chemotherapy in metastatic breast cancer: Swog s0500. J Clin Oncol 2014;32:3483-3489.

-94 Castells A, Puig P, Mora J, Boadas J, Boix L, Urgell E, Sole M, Capella G, Lluis F, Fernandez-Cruz L, Navarro S, Farre A: K-ras mutations in DNA extracted from the plasma of patients with pancreatic carcinoma: Diagnostic utility and prognostic significance. J Clin Oncol 1999;17:578-584.

-95 Nygaard AD, Garm Spindler KL, Pallisgaard N, Andersen RF, Jakobsen A: The prognostic value of kras mutated plasma DNA in advanced non-small cell lung cancer. Lung Cancer 2013;79:312-317.

96 Camps C, Jantus-Lewintre E, Cabrera A, Blasco A, Sanmartin E, Gallach S, Caballero C, del Pozo N, Rosell R, Guijarro R, Sirera R: The identification of kras mutations at codon 12 in plasma DNA is not a prognostic factor in advanced non-small cell lung cancer patients. Lung Cancer 2011;72:365-369.

-97 Frattini M, Gallino G, Signoroni S, Balestra D, Lusa L, Battaglia L, Sozzi G, Bertario L, Leo E, Pilotti S, Pierotti MA: Quantitative and qualitative characterization of plasma DNA identifies primary and recurrent colorectal cancer. Cancer Lett 2008;263:170-181.

98 Thomas E, Shaw RJ, Risk JM: Monitoring of circulating tumour-associated DNA as a prognostic tool for oral squamous cell carcinoma. Br J Cancer 2005;93:960.

99 Sozzi G, Conte D, Mariani L, Lo Vullo S, Roz L, Lombardo C, Pierotti MA, Tavecchio L: Analysis of circulating tumor DNA in plasma at diagnosis and during follow-up of lung cancer patients. Cancer Res 2001;61:46754678.

100 Yu AL, Gilman AL, Ozkaynak MF, London WB, Kreissman SG, Chen HX, Smith M, Anderson B, Villablanca JG, Matthay KK, Shimada H, Grupp SA, Seeger R, Reynolds CP, Buxton A, Reisfeld RA, Gillies SD, Cohn SL, Maris JM, Sondel PM, Children's Oncology G: Anti-gd2 antibody with gm-csf, interleukin-2, and isotretinoin for neuroblastoma. N Engl J Med 2010;363:1324-1334.

101 Matthay KK, Reynolds CP, Seeger RC, Shimada H, Adkins ES, Haas-Kogan D, Gerbing RB, London WB, Villablanca JG: Long-term results for children with high-risk neuroblastoma treated on a randomized trial of myeloablative therapy followed by 13-cis-retinoic acid: A children's oncology group study. J Clin Oncol 2009;27:1007-1013.

102 Pi3k inhibitor improves pfs in belle-2 trial. Cancer Discov 2016;6:115-116.

103 Zhang J, Zhang HD, Yao YF, Zhong SL, Zhao JH, Tang JH: Beta-elemene reverses chemoresistance of breast cancer cells by reducing resistance transmission via exosomes. Cell Physiol Biochem 2015;36:2274-2286.

104 Wang H, Hou L, Li A, Duan Y, Gao H, Song X: Expression of serum exosomal microrna-21 in human hepatocellular carcinoma. Biomed Res Int 2014;2014:864894.

105 Masyuk AI, Masyuk TV, Larusso NF: Exosomes in the pathogenesis, diagnostics and therapeutics of liver diseases. J Hepatol 2013;59:621-625.

106 Pink RC, Samuel P, Massa D, Caley DP, Brooks SA, Carter DR: The passenger strand, mir-21-3p, plays a role in mediating cisplatin resistance in ovarian cancer cells. Gynecol Oncol 2015;137:143-151.

107 Costa-Silva B, Aiello NM, Ocean AJ, Singh S, Zhang H, Thakur BK, Becker A, Hoshino A, Mark MT, Molina H, Xiang J, Zhang T, Theilen TM, Garcia-Santos G, Williams C, Ararso Y, Huang Y, Rodrigues G, Shen TL, Labori KJ, Lothe IM, Kure EH, Hernandez J, Doussot A, Ebbesen SH, Grandgenett PM, Hollingsworth MA, Jain M, Mallya K, Batra SK, Jarnagin WR, Schwartz RE, Matei I, Peinado H, Stanger BZ, Bromberg J, Lyden D: Pancreatic cancer exosomes initiate pre-metastatic niche formation in the liver. Nat Cell Biol 2015;17:816826.

108 Hurley JH, Odorizzi G: Get on the exosome bus with alix. Nat Cell Biol 2012;14:654-655. 